\title{
PORPHYRY, THE CAVE OF THE NYMPHS, AND THE MYSTERIES OF MITHRAS
}

\begin{abstract}
Summary: Porphyry's Cave of Nymphs is dedicated to deciphering the philosophical and theological significance of the cave described by Homer in the Thirteenth Canto of the Odyssey. However, within the exegesis of the Homeric cave awaits another exegesis concerning the cave in which Mithras sacrifices the bull and in which the initiation of the worshippers and the common meal take place.

According to Porphyry, the cave of the Nymphs is the place in which the worshippers were initiated into the platonic mystery of the descent and ascent of souls. Mithras, assimilated to the Demiurge of the Timaeus, generates souls by killing the bull he has caught, ridden and dragged into the cave which symbolises the cosmos. The souls, which are created by the bull/moon like bees in a sort of bougonia (cf. Virgil, Georgics IV), and which are animated by his blood, descend into the cycle of generation and incarnation and are dragged down by Boreas, the cold wind that keeps them cool in the place of earthly generation. After successive reincarnations the warm wind of Notus dissolves the carnal vestments that imprison them and returns them to the heat of the Sun.

Conclusion. After the comparison between the text of Porphyry and the CIMRM will show that the theme of the descent and ascent of souls is very weak in Mithraic finds, and the reading of tauroctony as bougonia remains deprived of iconographic evidence. To sum up, The Cave of the Nymphs is more relevant to the history of Platonism than to the history of Mithraicism.
\end{abstract}

Key words: bees, bougonia, Chaldaean Oracles, Homeric allegories, Mithraism, Platonism/Neoplatonism, reincarnation, Sun/Moon worship, tauroctony

The existence of a Platonic interpretatio of the cult of Mithras is well known, and has been thoroughly studied, mainly by Robert Turcan in his Mithras Platonicus (1975). As far as we know, the precursors of a Platonic interpretatio of Mithraism were Eubulus and Pallas, two Greeks believed to have lived in the time of Hadrian, or in the age of the Antonine emperors. Nothing more is known of their identity. ${ }^{1}$ Details on their interpretations are taken from Cronius and Numenius and are derived exclusively from

${ }^{1}$ TURCAN, R.: Mithras Platonicus. Recherches sur l'hellénisation philosophique de Mithra [ÉPRO 47]. Leiden 1975, 23-43. 
citations by Porphyry. Porphyry restates passages from Eubulus and Pallas in the Cave of the Nymphs and De abstinentia, and remains the fullest account, after that of Celsus, of the existence of a Mithras Platonicus.

I want to begin from the Cave of the Nymphs. The Cave is one of the early works of the Neoplatonic philosopher, pupil and editor of Plotinus, Porphyry of Tyre (c, $234-\mathrm{c}, 305 \mathrm{AD}$ ), belonging to the texts about Homer. Apart from several lost texts known only from quotes, the Homeric Questions and the Cave of the Nymphs in the Odyssey survive in large parts. The collection in which De antro nympharum (About the Cave of the Nymphs) was preserved may have been a mythological miscellany or an annotated copy of the Odyssey.

The cavern of the Nymphs is described by Homer in the Thirteenth Canto of the Odyssey. ${ }^{2}$ This is the cave of Ithaca where Odysseus, acting on the advice of Athena, hides the rich gifts received by the Phaeacians. Most of the work of Porphyry is dedicated to deciphering the philosophical and theological significance of the cave described by Homer, considered by Neoplatonists not only as a poet but also as a master of ancient wisdom and theology. However, within the exegesis of the Homeric cave there awaits, like a Chinese box, another but no less profound exegesis concerning the antrum of Mithras, the cave in which Mithras sacrifices the bull and in which the initiation of the worshippers and the common meal take place. Therefore Mithras' cave and Homer's cave mirror one another, both of them being in fact a hieroglyph of the cosmos.

The origin of the cult of Mithras is traced by Porphyry back to Zoroaster. Zoroaster - writes Porphyry, quoting Eubulus - was the first to consecrate to Mithras, the father and creator of all things, a natural cave near the mountains of Persia. ${ }^{3}$ The lair of Mithras is an 'icon of the cosmos' (Cave 6, p. 8. 18) and, not by chance, 'wherever Mithras was known, he was worshipped in a cave' (Cave 20, p. 20. 24-25). The Zoroaster of Eubulus, Pallas and Porphyry, of course, is not the original one, but that of the 'Hellenized' Magi, made newly compatible with the ancient Iranian divinities, and with Mithras in first place. In the Hall of Mithras, Porphyry continues, the worshippers were initiated into the mystery of the descent and ascent of souls.

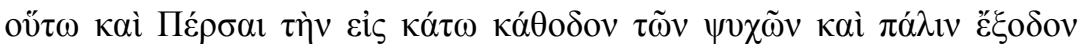

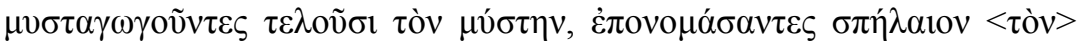

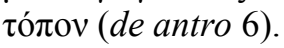

The Persians call the place a cave where they introduce an initiate to the mysteries, revealing to him the path by which souls descend and go back again (Cave p. 8. 13-15).

The passage in Porphyry, probably taken from the explicitly mentioned exegesis of Eubulus, is remarkable because, from what we read, the Mithraic mysteries seem finally to have been revealed. The core of the Mithraic mysteries, according to Porphyry,

\footnotetext{
${ }^{2}$ Hom. Od. 13. 102-112. Cf. Homeri Odyssea. Ed. P. VON DER MÜHLL. Lipsiae 1962.

${ }^{3}$ Cave 6. Cf. Porphyry, The Cave of the Nymphs in the Odyssey. A Revised Text with Translation by J. BARNES [Arethusa Monographs 1]. N.Y. at Buffalo 1969.
} 
is the doctrine of the descent of souls to Earth and their ascent to heaven from Earth. Later (Cave 11) Porphyry adds that souls have a natural 'inclination' (veṽoıs, Cave, p. 14. 14) for generation, and that the souls in question should be identified with the Naiad Nymphs who dwell in the Homeric or Mithraic cavern, which is an icon of the cosmos. In these passages one can sense echoes of the Chaldaean Oracles, which Porphyry knew well. The verb vev́ $\omega$ was not chosen at random, but refers to frr. 163 and 164 of the poem by Julian the Theurge (second half of the 2 nd century AD),

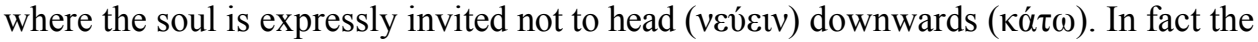
situation of living souls in the cave is ambivalent, in that it reflects the ambivalence of the cosmos itself.

Matter is in a state of flux ( $\dot{\rho} \varepsilon v \sigma \tau \tilde{\eta} \varsigma)$ and of itself lacks the form by which it can be shaped and recognized [...]. Because of matter, then, the Cosmos

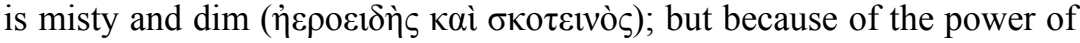
form for connecting and ordering (which gives the Cosmos its name), it is beautiful and pleasing. For this reason, then, it may be properly described as a cave that is pleasant when one first comes upon it because it partici-

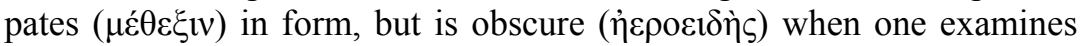
its foundations and penetrates with the mind to the depths of it - so that its exterior surface is pleasing and its interior and depths are dark.

[...] The Cosmos is both sacred and pleasing, although of its nature it is shadowy and misty. (Cave 5-6, p. 8; Cave 12, p. 14. 18-9).

In these passages we can sense the presence of the lexicon of the Chaldaean Oracles:

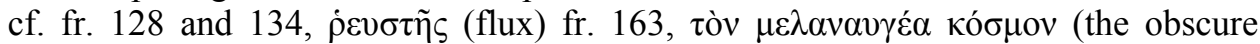
cosmos). In addition, the theme of the return or ascent of the soul is also one of the central themes of the Oracles, discussed by Porphyry himself in his De regessu animae. ${ }^{4}$ Returning to the relationship with Mithraism, it is striking, as noted by Turcan, ${ }^{5}$ how, in a work that establishes precise relationships between nymphs and Mithraism, there was no mention of Nymphus, the second degree of initiation into the cult. Although it is possible, as hypothesised by Turcan himself, that it was spoken of in the sources of Porphyry, Eubulus and Pallas, or Cronius and Numenius, it remains an incomprehensible omission. However, Turcan maintains that Porphyry was not an initiate and therefore this could account for this omission.

I shall come to the central point: according to Greek sources, Zoroaster was born five thousand years before the Trojan War, and therefore Mithraism - of which he is implicitly supposed to be the founder - is envisaged by Porphyry as the vector of a prisca philosophia or a perennial philosophy, centered on the mystery of the descent and ascent of the soul, and therefore the anticipation or the originator of Orphic-Pythagorean-Platonic themes.

\footnotetext{
${ }^{4}$ Cf. Porphyre, De regressu animae. In BIDEZ, J.: Vie de Porphyre le philosophe néo-platonicien. Gand-Leipzig 1913; réimpr. Hildesheim 1980.

5 TURCAN (n. 1) 68-69.
} 
The first question that arises here, and which I want to address now, is the following one: is the theme of the descent and ascent of souls indeed reflected in Mithraic remains? In other words, was there a problem of the soul in Mithraism? The first question can perhaps be answered in a graffiti found in the Mithraeum of Dura Euro-

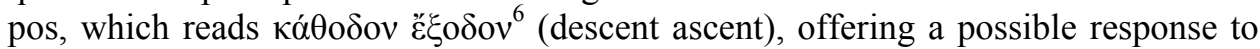
Porphyry Cave 8. 13-15. Secondly, it is known that images of Eros and Psyche are present in the Mithraea of Santa Prisca (here the fragment is out of context, and therefore not a sure testimony) and Santa Maria Capua Vetere, as well as on the magical

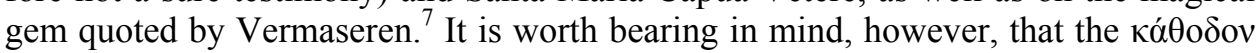

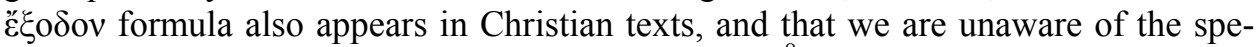
cific role of Mithras in the myth of Eros and Psyche. ${ }^{8}$ The doubt is reinforced by the fact that on the gem in question is engraved the word neicharoplex, frequent in magical papyri, and used mainly in erotic magic.

Proclus' Commentary on the Republic is not without bearing on this problem:

We must believe that this Ananke is identical to Themis. From this point of view not only are the Greek theogonies believable, but also the Persian initiations to Mithras, in the course of which all the epycleseis of Themis, from the beginning to the end, connect Themis to Ananke, as well as in in all the prayers. ${ }^{10}$

Themis is the goddess of justice, and Ananke that of necessity. In another place of the Commentary on the Republic Proclus quotes a work, attributed to Zoroaster, in which it is said that Ananke stimulates souls to come into being through domination of the winds. ${ }^{11}$ This theme, as we shall see, is also present in de antro of Porphyry. The distant source of this idea lies in the 'Laws of Fate' that the Demiurge of the Timaeus communicates to the newly created souls, but the theme was also taken up by the Oracles. One can therefore assume, hypothetically, that the reason for the descent/ascent of souls was also present in Mithraism.

I would like then to continue the analysis of the text of Porphyry. Mithras is there defined, on the basis of Plato's Timaeus 28c, as father and poietes of everything, the Demiurge of the universe (Cave 6, p. 8. 17-19), Demiurge and despot of generation (Cave 24, p. 24. 11-12), 'sustainer' ( $\sigma u v \varepsilon ́ \chi \omega v)$ of the cosmos (Cave 33, p. 32. 7). The last term is present in the Oracles: the synocheis are intelligible/intellectual gods in the so-called 'Chaldaean' system that Psellos obtained from Proclus. But it is espe-

${ }^{6}$ RostovzefF, M. I. - Brown, F. E. - Welles, C. B. (eds): The Excavations at Dura-Europos. Preliminary Report of the Seventh and Eighth Seasons of Work 1933-1934 and 1934-1935. New Haven 1939, 126 n. 863.

${ }^{7}$ VERMASEREN, M. J.: Corpus inscriptionum et monumentorum religionis Mithriacae. Den Haag 1956-1960 [CIMRM], no. 2356.

${ }^{8}$ See MASTROCInQUE, A.: Eros in the Mysteries of Mithras and in Graeco-Roman Paganism. MedAnt (forthcoming).

${ }^{9}$ MASTROCINQUE, A.: Studi sul mitraismo. Il mitraismo e la magia. Roma 1998, 28 and 34.

${ }^{10}$ Procl. In Plat. Rem publ. II 345,4 Kroll. Cf. Proclus, In Platonis rem publicam commentarii. Ed. W. KROLL. Vol. I-II. Leipzig 1899-1901; French transl. by A.-J. Festugière. Paris 1970.

${ }^{11}$ Procl. In Plat. Rem publ. II 109. 7 ff. Kroll. 
cially the use of the term 'father' which, in addition to a Platonic association, refer to the Oracles, in which it characterizes both the first and the second deity. The second deity is in every respect a Demiurge which extracts from the First Paternal Intellect the models of the sensate cosmos. In Numenius, however, the term 'father' is reserved only for the first god, who is not active but 'idle'. But how does all this compare to Mithraism?

The demiurgic function of Mithras is not made clear by any Mithraic remains. According to Gershevitch ${ }^{12}$ this is implicit in the rain bestower function that Mithras derived from Varuna. The rain bestower function is widely reflected in the "miracle of the rain' omnipresent in all the upper panels framing the tauroctony. In modern times George Gemistos Plethon, by putting together the Second pseudoplatonic Epistle, the Iranian section of Plutarch's Isis and Osiris, the Chaldaean Oracles (renamed Oracles of Zoroaster) and Plotinus, believed he could identify Mithras with the dis epekeina (Twice Transcendent), the second Intellect of the Oracles which, unlike the first, is active, and therefore also has demiurgical functions. The most important manifestation of the demiurgic function of Mithras, according to Porphyry, is the tauroctony, understood as the divine act par excellence. As a preliminary, Porphyry offers an explanation of the scenario in which it occurs.

The equinoctial region they assigned to Mithras as an appropriate seat. And for this reason he bears the sword of Aries, the sign of Mars; he also rides on a bull, Taurus being assigned to Venus. As a creator and lord of genesis, Mithras is placed in the region of celestial equator with the north to his right and the south to his left; to the south, because of its heat, they assigned Cautes and to the north $<$ Cautopates $>$ because of the coldness of the north wind. With good reason they assigned winds to souls proceeding to genesis and departing from it because they as well drag spirit along with them, as some have supposed, and possess a like essence. (Cave 24-25, p. 24.9 ff.)

Porphyry makes clear that Boreas befits souls descending into generation because it freezes them. Notus is convenient for the souls that go back because it dissolves ( $\delta 1 \alpha-$

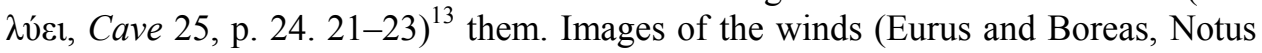
and Zephyrus) can be found in some Mithraic remains, for example in the relief of Modena (CIMRM 695/6), the framework of the (rotating) Heddernheim (Germany, CIMRM no. 1083) and Dieburg (Germany) reliefs (CIMRM no. 1247). A reading of Mithras at the centre of the equinoxes, introduced by Porphyry, is still the most widespread. Mithras, says Porphyry, is placed between the spring equinox (Aries) and autumn equinox (Libra), and among the most recent equinoctial signs. But Porphyry is aware that in most Mithraic reports (especially those of Octavian Zeno on the Celian hill) ${ }^{14}$ the vernal equinox was still symbolized by the bull, Taurus, and autumn by

\footnotetext{
${ }^{12}$ Gershevitch, I.: The Avestan Hymn to Mithra. Cambridge 1959, 32.

${ }^{13}$ Cave 25.

${ }^{14}$ Cf. VERMASEREN, M. J.: Mithriaca IV [ÉPRO 16]. Leiden 1978.
} 
Scorpio. This forces Porphyry into a kind of escamotage, leading him to make the machaira, the short dagger with which Mithras kills the bull, into the symbol of Mars, ruler of the zodiac sign of Aries, and Venus, ruler of Taurus, into the symbol Libra (the other house of the goddess).

Now we come to the central point of the Porphyrian reading. Porphyry interprets tauroctony as the act of the souls' generation, in which they, like bees, are born from the sacrificed bull: but the bull also represents Selene, the moon.

The Moon, who presides over genesis, was called by them the Bee, especially since the Moon is also known as a bull and Taurus is its exaltation, while bees are ox-born and the god who secretly furthers creation is called the ox-stealer (bouklopos; Cave 18, p. 20. 2-6). ${ }^{15}$

Let me summarize the overall significance of these steps. Mithras, assimilated to the Demiurge of the Timaeus, generates souls by killing the bull he has caught, ridden and dragged into the cave which symbolises the cosmos. The souls, which are created by the bull like bees in a sort of bougonia (cf. Virgil, Georgics IV $284 \mathrm{ff}$.), and which are animated by his blood, descend into the cycle of generation and incarnation and are dragged down by Boreas, the cold wind that keeps them cool in the place of earthly generation. After successive reincarnations (which we will examine immediately after the passage about Porphyry) the warm wind of Notus dissolves the carnal vestments that imprison them and returns them to the heat of the divine, in other words, to the Sun. Porphyry then adds some details that remind one of the passages in the final part (945 C) of the De facie by Plutarch:

The Theologians make the Sun and Moon gates for souls, and say that they ascend through the Sun and descend through the Moon (Cave 29, p. 28. 24-25).

But Numenius is also called to mind.

In a stricter sense it is the power presiding over waters that we call naiads nymphs, but the ancients also give this name to all the souls in general descending into genesis. For they thought that the souls settle by the water, which is divinely inspired, as Numenius says. [...] And he quotes Heraclitus as saying 'it is a delight, non death, for souls to become moist'. (B 77 D.-K.)

[...] Blood and moist seed are dear to those souls [...]. It is inevitable, then, for souls $[\ldots]$ to incline towards moisture and to be embodied by a process of moistening [...]. But pure souls are averse to genesis, and Heraclitus himself says 'the dry soul is wisest'. (B 118 D.-K.; Cave 1011, p. $12.15 \mathrm{ff}$.)

In the context of this interpretation particular attention is paid by Porphyry to the purifying role played by honey. The identification of the souls born from the bull killed

${ }^{15}$ Cave 18. Cf. the mysta booklopies of Firm. Err. 64. 4 Pastorino. 
by Mithras with bees born of ox carcass amply justifies the interest, which arises especially in relation to the cultic rank of leo. In this case we have, for once, a textual confirmation because a Steklen inscription in Bulgaria reads leo/melichrisus, thus confirming that the purification of leones was through honey.

For this reason it is in the mixing-bowls and amphoras that bees store honey; mixing-bowls bear a symbol of springs, just as the mixing-bowl is set beside Mithras in place of a spring [...]. The theologians indeed make use of honey for many different symbols because it is a combination of many powers, both cathartic and preservative. Many things are kept from rotting by means of honey and chronic wounds are cleaned out with it. Further, it is sweet to the taste and is gathered from flowers by bees who happen to be born from an ox. So in the Lion mysteries, when honey is poured instead of water for purification on the hands of the initiates, they are exhorted to keep them pure from everything distressing, harmful and loathsome; and since he is an initiate of fire, which has a cathartic effect, they use on him a liquid related to fire, rejecting water as inimical to it. They use honey as well to purify the tongue from all guilt. When, on the other hand, they offer honey to the Persian as the preservative of fruits, it is its preservative powers that they treat symbolically (Cave 17, p. $18.23-26$ and 15 , p. 16.20 ff.).

As we have seen, Porphyry, like Celsus, attributes to Mithraism a doctrine of the descent and ascent of the soul, and in particular one of the transmigration doctrine. The relevant passage can be found in Porphyry's De abstinentia.

The Magi were divided into three grades, according to the assertion of Eubulus, who wrote the history of Mithraism in many books. Of these the highest and most learned neither kill nor eat any living thing, but practise the long-established abstinence from animal food. The second use such food, but do not kill any tame beasts. And, following their example, not even the third permit themselves the use of all. For in all the highest grades the doctrine of metempsychosis is held, which also is apparently signified in the mysteries of Mithras: for these through the living creatures reveal to us symbolically our community of nature with them. So the mystics who take part in the actual rites are called lions, the women hyænas. the servants crows, and the fathers bear the names of eagles and hawks. He who is invested with the character of the lion adopts various forms of living creatures, the reason for which is said by Pallas, in his work on Mithras, to be the belief in their common life-history, which "extends over the course of the zodiacal cycle; but a true and precise conception of human souls is set forth in symbol, for these they say pass through various bodies". ${ }^{16}$ 1990,50

${ }^{16}$ Porph. De abst. IV 16. 1-4. Cf. GEDEN, A. S. - RonAn, S.: Mithraic Sources in English. Hasting 
The passage is notable also because it is one of the not uncommon examples of the presence of women in Mithraism - a presence which is denied even today, in spite of this and other evidence, the latest of which being one of the lateral frescoes of the Mithraeum of Aquincum (Budapest). ${ }^{17}$ Apart from that, it offers a Pythagorean-Platonic interpretation of the animal masks worn by the initiates, visible especially in the relief of Konjic (Sarajevo). ${ }^{18}$

The citations I have mentioned are the passages of Porphyry most directly related to the exegesis of the cult of Mithras. Now my intention is to bring forth from the very same citations a series of further exegetical consequences that are not spelled out explicitly in them. The exegesis of Porphyry understands tauroctony in the light of the Timaeus. Given this overlap, it should be deduced that the bull has the same functions as the Chora (the space-matter of the Timaeus). Like the Chora, the bull is the fertile substance from which the material cosmos is born. However, just like the bull, Chora is recalcitrant, and must be tamed by the Demiurge. In the Timaeus the Chora has a parallel in the intelligible world, namely of that which is different. The Demiurge, in the words of the text, overcomes by force the natural resistance of 'the different' to being assimilated (35a6-35b3). This same act of force is repeated against the chora, which is 'tamed' through geometric figures (especially the four regular polyhedra).

Something of a similar nature happens in Mithraism. The definition of Mithras as 'thief of oxen', bouklopos, used by Porphyry in The Cave of the Nymphs, but also by Firmicus Maternus and Commodianus (who compares Mithras to the Cacus of Virgil: vertebat boves alienos semper in Antris / Sicut et Cacus Vulcani filius ille) ${ }^{19}$ has all the appearance of a key epithet. Leaving aside the sarcastic tone of Commodianus, the comparison with Cacus at first sight is appropriate, because in the transitus while Mithras drags the bull away by the hind legs, its front legs dig into the ground, leaving hoofmarks that lead in the opposite direction to that of Mithras. This was exactly the trick used by Cacus to put the livestock owners and Hercules himself off the right track. ${ }^{20}$ However, in the case of Mithras the term 'thief' of oxen can only refer to the 'stealthy' way Mithras had to approach the reluctant bull (because it would have been paradoxical if a god whose specific function, in the Avesta, was to punish cattle thieves, had himself become a thief of the same). In fact the iconography of transitus accentuates the unwillingness of the bull, showing it desperately straining in the opposite direction to that taken by Mithras. The reluctance of the bull forces Mithras at first to engage in a kind of rodeo with the bull, ${ }^{21}$ and finally manages to hold it

${ }^{17}$ Cf. PÓczy, K.: Aquincum. Budapest a római korban - Das römische Budapest. Budapest 1990, fig. 11 "Mithras-Heiligtum im Haus des tribunus laticlavius" and fig. 12.

${ }^{18}$ CIMRM no. 1896.

${ }^{19}$ Firm. Err. 64. 4 Pastorino; Porph. De antro 69. 16 Nauck; Comm. Instr. I 13.

${ }^{20}$ Verg. Aen. VIII 209-211: atque hos, ne qua forent pedibus vestigia rectis,/cauda in speluncam tractos versisque viarum/indiciis raptus saxo occultabat opaco. Cf. VERMASEREN, M. J.: Mithra, ce dieu mystérieux. Paris-Bruxelles 1960, plates 19-22. Cf. relief of Neuenheim, in MERKELBACH, R.: Mithras. Eine persisch-römischer Mysterienkult. Wiesbaden 1984, fig.116 (= CIMRM no. 1283).

${ }^{21}$ Cf. VERMASEREN: Mithra (n. 22) plates 21-23. 
still with the force of the left knee pressing on the animal's back, and with the left hand holding its head ${ }^{22}$ still the machaira, the short sword, sinks into its neck and makes the blood flow profusely.

The most problematic point of the Porphryian exegesis remains the interpretation of tauroctony as bougonia. In Mithraic reliefs, as well as in the Pahlavi texts, vegetables, plants and all the species of animals spring forth from the slain bull, as symbolized by the ear of corn that sprouts from the tail or from the wound inflicted by Mithras. If the tauroctony were indeed similar to a bougonia, as claimed by Porphyry, we would expect to see the bee symbol on some monument. But the presence of bees in Mithriac finds is very poor. The only monuments in which Merkelbach deciphers the presence of bees are the relief of Viale Manzoni in Rome (CIMRM 334) and a Mithriac gem (CIMRM no. 2354). The first case is doubtful, because the comparison with a print of 1700 that shows a clearer picture than the relief itself $^{23}$ and which contains no bees. The second, which shows a bee departing in front of the mouth of a lion, could confirm the relationship between Leo and honey of which both Porphyry and the inclusion of Steklen speak (CIMRM no. 2268). But it could even be a biblical quotation (OT, Judges 14:12 ff.), which alludes to the variant of bougonia that sees bees emerge from the carcass of a lion instead of a bull.

I believe that behind the Porphyrian exegesis of tauroctony there is, on the one hand, the identification of the bull with the moon, which finds its confirmation in Avestan and Pahlavi texts ${ }^{24}$ and the reliefs around the tauroctony (the recurring theme of the bull in scapha lunata). The other, a myth of Indo-Iranian origin, is echoed in the final part of the De facie by Plutarch, according to which souls are born from the moon. However, in none of these texts bees are mentioned. The only work in which bees appear in the context of a demiurgic act is the fr. 37 of the Chaldaean Oracles, where, however, the bee is only a Homeric metaphor. In the long fragment in question, quoted by Proclus in the Commentary on the Parmenides, the bees are similar to second level noemata (or logoi spermatikoi Stoics or neo-Kantian 'rules of construction') which depart from the Intellect towards the wombs of Hecate, the cosmic Soul, to inseminate them and thus give rise to life. Given that Hecate is also the moon, the literary/artistic taste of Porphyry - or his sources - may have overlaid, elaborated and moulded all this material to obtain a coherent picture. It is evident, however, that this exegesis does not correspond either to the more traditional image of the tauroctony or to the variant depictions of Mithras just before sacrificing the bull (Panticapaeu, Viale Manzoni and Mithraeum of Santa Prisca in Rome, Mithraeum of the Baths in Ostia, the coin of Tarsus, etc.). The only passage of Porphyry in tune with what is seen in the tauroctony is when he says that the souls love 'blood and moist seed' (Cave, 10-11, pp. 12:15 ff.). In fact, we always see in the tauroctony a dog and a snake

${ }^{22}$ Cf. Statius, indignata sequi torquentem cornua Mithram (Theb. I 716-20) Cf. SANZI, E.: I culti orientali nell'Impero romano. Un'antologia di fonti. Prefazione di G. Sfameni Gasparro. Cosenza $2003,411$.

${ }^{23}$ Cf. TURCAN, R.: Mithra et le mithriacisme. Paris 1981, plate 8. $132-133$

${ }^{24}$ Cf. Yast 7, Yast 12.25 and WeST, M. L.: La filosofia greca arcaica e l'Oriente. Bologna 1993, 
licking the blood gushing from the wound, and a scorpion licking the seed that spurts from the penis and the testicles of the bull. And yet it should be assumed, to give support to this reading, that the animals of Mithras are reincarnated souls in those remains, namely that souls are represented by the constellations that govern them. Even if we were to accept this, however, the tauroctony would not portray the birth of souls or bees from the bull, but their sustenance through blood and sperm. Once again, this interpretation may not be found in the Porphyrian exegesis, but in one of the hexameters of Santa Prisca in Rome, the controversial et nos servasti aeternali sanguine fuso, and interpreting the tauroctony as bougonia would remain again deprived of iconographic evidence.

This being said, there remains the question raised by $\operatorname{Turcan}^{25}$ as to whether the tauroctony as bougonia might not have been alluded to in a cryptic way by Virgil himself in the fourth book of the Georgics, with Virgil being a possible depositary of Mithraic mysteries revealed to him by the mysterious old man of Corycus, a former pirate of Mithridates integrated by Pompey into the Roman social circles, according to Servius. ${ }^{26}$ Could then the real significance of the central event in the cult of Mithras have been communicated only orally, as were the 'unwritten doctrines' of Plato? And what if the tauroctony was an exoteric facies of an esoteric event known only to a few, namely the bougonia? It is a fact that we know little or nothing of the most secret parts of those initiation mysteries different from what we know of Mithraism, such as those of Eleusis, or Isis and Osiris, or Serapis, in spite of the greater abundance of literary evidence.

In any case, I prefer to abandon this 'broken path', and deal with the problem of the meaning of the tauroctony from another point of view. Six years after publishing the Mithras platonicus, Robert Turcan presented a report to the Hardt Foundation in 1981, Le sacrifice mithriaque. ${ }^{27}$ In it Turcan put forward the anomalous character of the sacrifice of the bull in relation to the existing Greco-Roman context. In particular, he observed: 1) That the victim, who in the Greco-Roman sacrifice was usually consenting, in Mithraic sacrifice was not at all doing so, in fact he was stubbornly reluctant (as seen from the previous analysis). 2) That the main purpose of Mithras was not to kill the victim, but take away its blood: the death of the bull was, as it were, a 'side effect' of large wound inflicted. 3) That the god-Mithras - this time - was not the beneficiary of the sacrifice, but the officiating figure. 4) That the sacrifice was intended to 'reinvigorate' and 'sustain' other creatures through the blood and sperm (cf. Santa Prisca in Rome, et nos servasti aeternali sanguine fuso) again with the paradoxical result that the sacrifice was done for the benefit of man instead of the gods.

Putting all these facts together, and taking into account the setting of the sacrificial act which takes place in a cave reflecting an image of the cosmos, the sacrifice

${ }^{25}$ TURCAN (n. 1) 8-9 and 73.

${ }^{26}$ Cf. TURCAN (n. 1) 8-9, 73 .

${ }^{27}$ TURCAN, R.: Le sacrifice mithriaque : innovation de sens et de modalités. In Le sacrifice dans l'antiquité [Entretiens sur l'antiquité classique, Tome XXVII]. Fondation Hardt, Vandœuvres-Genève 1981, 341-372 (reed. Roma 2001). 
of the bull or tauroctony takes on the meaning of an act of regeneration and refoundation of the cosmos and of the creatures living in it by a god, Mithras, who represents its 'supporting element' and the guarantee of eternity. What comes to mind in this regard are the many images of Mithras Cosmocrator (CIMRM nos 334, 985, 1289 , etc.), or the image of the 'pagan cross', the chi (X), the intersection of the equator with the ecliptic drawn on the cosmic globe (CIMRM 1027b), the Platonic Anima mundi character (taken up in recent times by Heidegger as protection of Being). As we have seen, this meaning was grasped in part by the same Porphyry, when he called

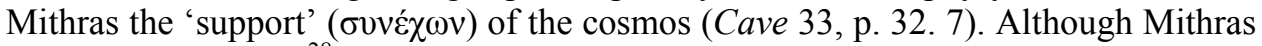
'is not a Demiurge', ${ }^{28}$ the 'protective' or 'fatherly' function belongs to a Demiurge. The Demiurge, as Plato says in The Statesman (270a, $273 \mathrm{~d}-\mathrm{e})$ reappears on the scene just when the cosmos needs to be 'reset'.

Luciano Albanese

Department of Philosophy,

University of Rome 'La Sapienza'

Italy

${ }^{28}$ TURCAN: Le sacrifice (n. 29) 369. 
